\title{
Value Added Tax: An Instrument used in some African Countries to Meet Fiscal Objectives
}

\author{
K.R. Chauke* and M.P. Sebola
}

\author{
University of Limpopo, South Africa
}

\begin{abstract}
This article aims to evaluate the extent at which VAT is used as an instrument by countries to meet their fiscal deficit and meet the needs of their citizenry. Taxpayers pay taxes based on their ability to pay and with an anticipation that they will receive services in return to their contribution from government. The VAT due to its buoyancy nature contributes sizable amount of taxes which alleviate the financial burden of countries in meeting the financial obligations. Numerous kinds of literature demonstrate that whenever countries experience any budget shortfall they always look for fiscal remedies in either introduction of VAT or changing the rate of VAT. South Africa recently changed its long term rate of $14 \%$ VAT to $15 \%$. This article is conceptual in approach and uses the literature to argue that Value Added Tax (VAT) can be used as an effective instrument to meet fiscal objectives in some African Countries. Countries have the responsibility to ensure that their subject contributes to taxes which amongst others should in the form of VAT. As in the case of other taxes, the taxes are used to meet the fiscal obligation a country faces. The paper concludes that many countries that have introduced VAT have managed to meet their fiscal obligation due to high revenue contribution that have emanated from it, making the VAT the best tax methods to enable the country to meet their fiscal obligations.
\end{abstract}

Keywords: Fiscal, Fiscal Objectives, Instrument, Value Added Tax.

\section{INTRODUCTION}

The reliance on taxation in human history evolved over the years and governments started to place policies that positioned taxes to play a prominent role in the economic life of their countries. Such policies included those designed to attain distribution of income and wealth and increasing the rate of national economic growth (Fjeldstad \& Moore, 2009). The earliest and most powerful way in which the government interacted with the economic life of individuals and business enterprises has been through taxation at the most. The interaction between the government and the right of the revenue authorities to collect taxes, and the general policy which set out the rules as to who is to be taxed, and setting the parameters of how much tax should be levied and the outlining of the purpose for which it shall be levied has always been a contentious and controversial issue (Fjeldstad \& Moore, 2009). Despite the government's responsibility to collect taxes by making use of the revenue authorities, it remains a challenge to establish an appropriate tax base and getting the appropriate level of compliance from the taxpayers. The research question to be addressed or answered in this article is whether or not the Value Added Tax can be used by African countries to meet their fiscal objectives? In answering the question, the article provides a theoretical perspective of the argument, tax and revenue collection, Tax theories and VAT Contribution

*Address correspondence to this author at the University of Limpopo, South Africa; Tel: 015268 2649; Fax: 015268 3522;

E-mail: richard.chauke@ul.ac.za to countries fiscus, impact of VAT in some African countries and whether or not the VAT improve the countries fiscus obligations?

\section{THEORIES OF TAXATION}

Theories are naturally embedded with critical tools and they are also used as analytical tools that are utilized for understanding, explaining concepts and construct, and they can also be used in making predictions about the subject matter that is being studied (Swanson, 2000; Lynham, 2002; Welp, VegaLeinert, Stoll-Kleemann \& Jaeger, 2006). Theories in various fields of study are expressed in natural language, but they are always constructed in such a way that their general form is identical to a theory as it is expressed in the formal language (Zott, Amit, Massa, 2010). Theories of taxation are founded and entrenched on canons that Adam Smith, the father of the modern political economy has laid down in his famous book "Wealth of Nations'. He laid down four principles, and these principles are still considered to be the starting point of sound public finance management. Numerous theories exist in taxation. Governments at all levels need to raise revenue from a multiplicity of sources to finance public sector expenditures (Smith, 2005; Fjeldstad \& Moore, 2009). Many theories guide the levying of taxation. In the above discussion, the focus was on the principles of taxation. For a tax system to be regarded as good or not, certain elements are critical to that conclusion. Certain salient features are essentials of a sound tax system. There are principles of a sound tax system which includes the following: A good tax system should 
also be structured in such a way that it has the ability to yield sufficient revenue to the government so as to enable the government to meet the need that the citizenry expects and requires, which is one of the significant responsibilities faced by the government (Bird \& Zolt, 2003; Huxham \& Haupt, 2018). The cost that is spent on collection of taxes should not be excessive, because when it is costly to collect the taxes, it will have an impact on the amount of taxes collected, the percentage cost of collection to tax collected should be nominal (Young, 1986; Waris, 2007). For purposes of this article two theories of taxation are applicable and relevant for discussion and they are: Who will benefit theory and the ability to pay theory.

\section{Who will Benefit Theory?}

Where the benefit theory is used, the tax levels are automatically determined because taxpayers pay proportionately for the government benefits that they receive (Ramsey, 1927; Chigbu, Eze \& Ebimobowei, 2012). The individuals who benefit most from the public services pay the most taxes. It can, however, be argued that this can be theoretical rather than practical because the government usually provide standard services to everyone without considering as to who is the main contributor of taxes (Ebimobowei \& Ebiringa, 2012). In analysing the who will benefit theory the Lindahl and the Bowen model can be used, which is focused in trying to resolve the three problems which are: The extent of state activities; Allocation of the total expenditure among the various goods and services; and allocation of the tax burden (Rai, 2004; Chigbu, Eze \& Ebimobowei, 2012). In the case of the Bowen model, it demonstrates that when social goods are produced in circumstances wherein there is increasing costs, the opportunity costs of the private goods are sacrificed (Rai, 2004; Chigbu, Eze \& Ebimobowei, 2012).

The who will benefit theory indicates that there is a direct correlation that exists between revenue and expenditure that is in a budget, and it approximates market behaviour in the allocation procedures and processes of the public sector (Chigbu, Eze \& Ebimobowei, 2012). Despite the who will benefit theory being regarded as simple; it, however, has a certain number of inherent difficulties that are embedded in the model and they include evidence from the discussion above that the who will benefit theory has the propensity to can limit the scope of government activities because the element of who will benefit will have to play a role in the government decision and this is not practical as is not all citizens who will have the capacity to pay for the services that they receive. Pursuing this way of reasoning can also make it difficult for the government to support the poor or take steps that will be aimed at stabilising the economy because their decision-making processes will have to be influenced by who will benefit from such actions.

\section{The Ability to Pay Approach}

On the ability to pay approach, the government revenue and expenditures are treated separately, and taxes are based on the taxpayer's ability to pay, and it derives from wealth as well as current income and there is no 'quid pro quo' (Chodorow, 2008; Chigbu, Eze \& Ebimobowei, 2012; Zhou \& Madikeri, 2013). Taxes paid are seen as a sacrifice by taxpayers, which raise the issues of what the sacrifice of each taxpayer should be and on how the measurement of such sacrifice should be done (Rai, 2004). The common sacrifices are the same and equal marginal sacrifices and equal proportional sacrifices. Equal sacrifice, in using this principle, the total loss of utility as a result of taxation should be equal for all taxpayers, and the rich will be taxed more heavily than the poor (Young, 1986).

\section{TAXATION AND REVENUE COLLECTION}

The orthodox view of taxation is that the revenue collection is one of the significant functions for any state to sustain itself (Smith, 2003). The government has the responsibility to collect taxes and not to announce a tax system and hope that taxpayers through their sense of responsibility will comply and remit what is owed to the fiscus (Smith, 2003; Slemrod, 2007; Croome \& Olivier, 2010). As the government does not have unlimited resources to meet the needs of the citizens, they have the responsibility to raise revenue to meet its expenditures and these revenues should be sourced from taxes (Bird \& Zolt, 2003). In the process intended to collect these taxes, the government has to contend with the conventional view that no tax system is perfect; however, the government has to ensure that the type of tax that they impose conform to certain principles that achieve its objectives without producing adverse effects. Taxation and revenue collection as we understand it today is deeply rooted from Adam Smith.

\section{Adams Smith and Taxation}

In his book, the Wealth of the Nations (1776) Adam Smith proposed that a sound tax system should 
possess the features that encompass equity, certainty, convenience and efficiency (World Bank, 2007:20). As much as these principles are ancient, they are still relevant in modern tax systems (World Bank, 2007:20). Revenue emanating from tax is the most important source of public finance, and it is a compulsory payment that is levied by the government on individuals or companies to meet the expenditures that are required for public welfare (Dalton, 1992). According to Dalton, public authority imposes compulsory contribution called tax without regard to the services rendered to the taxpayer and is not charged as either penalty or for any offence (Dalton, 1992). In this book, Adam Smith only dealt with four canons of taxation. With the change in time and as governance expanded it became much more complicated than what it was at the time of Adam Smith and there was a need that was felt by modern economist to expand Smith's principles of taxation, and as a response, they put forward some additional canons of taxation. Adam Smith's main canons of a sound tax system were four initially, and these were the canons of equity, certainty, convenience and economy. The additional ones that were later incorporated were called principles, and they are the principle of productivity, elasticity, flexibility, simplicity, and diversity. All combined could be referred to as the principles, but the commonly used terminology by Adam Smith was that of canons. It must, however, be emphasised that a sound tax system is the one that is designed based on an appropriate set of principles or rules and it is vital to strike a balance between the tax authorities and the interest of the taxpayers. There is no doubt that the activities and function of government have grown and increased significantly since the time of Adam Smith and the government are now expected to maintain economic stability, full employment, reduce income inequality and also to promote growth and they have ensured that there is development and it expected that a tax system must be able to meet these government requirements.

\section{Adam Smith Canons of Taxation and Modern Economists}

The discussion that follows will first discuss the four principles which were initially termed the four canons of the sound tax system by Adam Smith, that will be followed by the new principles as added by modern economists. Value Added Tax, as a tax should be based on varied principles that all taxes are based on and in this article the focus will be on the sixteen principles/canons which include the following: equity, certainty, convenience, economy, productivity, elasticity, flexibility, simplicity, diversity, neutrality, tax efficiency, administrability, stability, sufficiency, equality or ability and invisibility.

VAT as another form of tax has to adhere to these principles, and they provide for economic and social justice to the people (Batt, 2012). These principles indicate that every person should pay to the government depending upon his ability to pay (Batt, 2012). It is expected that the wealthy class of people should be the ones that pay higher taxes to the government because in the absence of the protection of the government authorities like police and defence could not have earned and enjoyed their income. It can, therefore, be argued that this is one of the critical principles of tax, in that it is expected of tax to provide equity in its application. Tax however, have to be certain and the taxpayer should be definite and certain about the amount of the tax and the time of payment (Williams, 2001; Waris, 2007). The levying of tax should be at the time, or in the manner in which it is most likely to be convenient and suited for the taxpayer or contributor to pay (Chigbu, Eze \& Ebimobowei, 2012). VAT is regarded as one of the most convenient taxes, as it is a self-assessment tax. The convenience of the tax system will encourage people to pay tax and will increase tax revenue. It can, therefore, be argued that the cost of collecting VAT is not exorbitant is it is a self-assessment tax and payment of tax due it the responsibility of the taxpayer based on the outcome of the assessment, and it therefore complies with the principles of economy (Chigbu, Eze \& Ebimobowei, 2012). VAT can be increased and decreased as and when necessary, it therefore meet the requirement of elasticity of the principle of tax (Waris, 2007; Chigbu, Eze \& Ebimobowei, 2012). It is the responsibility of the government or revenue authorities to increase or decrease their taxes according to the requirement of the country (Waris, 2007; Chigbu, Eze \& Ebimobowei, 2012).

The concept administrability refers to the ease with which a tax can be administered and collected. Collection of VAT, is not burdensome (ACOIR, 1974; Batt, 2012). Taxes which distort the economy are inefficient and costly to administer. Tax will be regarded as stable if it can produce revenue to finance government expenses despite the changing economic circumstances of the time (Allan, 1992; Batt, 2012). An ideal tax system should also comply with the principle of equality. The equality principle captures the ability to pay and the benefits principles, which plays a pivotal 
role in taxation (Martinez-Vazguez, 2001; Rai, 2004; Batt, 2012).

The benefit principle mandates that those who benefit the use of commodities or services should be required to pay for such benefit use. The benefit principles are used as a justification for the imposition of an indirect tax, such as a Value Added Tax (Martinez-Vazguez, 2001; Pfister, 2009). The principle of invisibility relates to the notion that the best taxes are those paid by the other people, like in the case of corporate tax and non-tax revenue which is not directly paid by the individuals, which is then referred to as invisible tax and the best taxes are therefore those taxes which extracts the spending power from the private sector before it has accrued it or to any particular individual (Gemmell, Morrissey \& Pinar, 2010).

\section{TAX THEORIES AND VAT CONTRIBUTION ON COUNTRY'S FISCUS}

A strong economy is reliant and dependent on the sound taxation and fiscal policy because they can create the underlying foundation for economic development in a country. Taxation and fiscal policy have driven countries to very different directions which includes successful outcomes, mediocre and failures or even to the combination of the different outcomes (Zolt \& Bird, 2003; Rai, 2004; Mylek, 2008; Pfister, 2009). Taxation is divided into direct and indirect taxes; the tax which was initially levied on taxpayers is the direct tax (Huxham \& Haupt, 2018; Pfister, 2009). Direct taxation is regarded as necessary due to the historical reliance on it as a significant source of income and the focus on indirect tax was pursued later in the levying of taxes (Aasness, Benedictow \& Hussein, 2002; Kayaga, 2007). The increased focus on indirect taxation can be best illustrated by looking at the incomparable interest that value-added tax has received in the last century and the number of countries that have introduced Value Added Tax. Value Added Tax, which is an indirect tax has become one of the significant sources of revenue for many countries (Aasness, Benedictow \& Hussein, 2002; Akintage \& Tashie, 2013; Weber, 2012). It must, however, be reported that it is not possible for the total revenue to be collected from indirect taxes only. There is, therefore, a need to have a diversity of sources of revenue. As one of the principles of tax, VAT have to affect everyone equally, which means that the poor will end up bearing the same burden as the rich, because the VAT rate is the same for everyone. It can further be argued that the reality of the tax burden is that the burden borne by the poor is more substantial because the poor are taking from the least while the rich are taking from abundance and the unfortunate end up being worst off as compared the rich which is contrary to the ability to pay theory.

Taxation is one of the major focus that continued to occupy a critical space in the writing of the classical economists such as David Ricardo, James Mill, Adam Smith, Jean-Baptiste Say and others (De Long, 1982; Aspromourgos, 2001). This, therefore, means that taxation originates in economics and it can thus be argued that it is an economic concept and it has the influence in the economic growth of countries if not well managed, because the higher rate of tax makes the goods and services produced expensive and direct impact on the use of such services. The tax rate has impact on the competitiveness of a country, and investors consider the implication of tax rates on their goods and services that they produce before making investment decisions. The cash in the hands of the taxpayers, that can be available for them to spend, is also reduced, if the rate of tax is too high, hence the many protest that accompany VAT rate increases in countries, as was the case in South Africa in 1991 with the introduction of VAT and in Ghana, in 1995, which resulted in the withdrawal of introduction of VAT (Go, Kearney, Robinson \& Thierfelder, 2004; Andoh, Osoro \& Luvanda, 2018). It can, therefore, be argued that, if taxation is not well administered it can have severe consequences for the economy of the country and the country can fail to meet the needs of the country.

\section{IMPACT OF VAT IN SOME OF THE COUNTRIES WHERE INTRODUCED}

In early 1980 , there was a project undertaken by International Monetary Fund ('IMF') in Sub-Saharan Africa to undertake a project of the structural adjustment programme, which was aimed at strengthening the introduction of a broad-based consumption tax. This programme was the one that came with the VAT, which was used as a tool to address the inefficiencies that were prevalent in the tax system. It was thought that the introduction of VAT would boost the domestic revenue as it was regarded as "fiscal pull" (Andoh et al., 2018). In 2018, out of 54 African countries, only six have not introduced VAT (Andoh et al., 2018). The fiscal impact of VAT differs from country to country as they implement different zero rating, exemptions, standard rating, rates, schemes and threshold levels. The VAT was adopted 
in South Africa in 1991, and since then, it has become the second contributor to the fiscus (Go, Kearney, Robinson \& Thierfelder, 2004). In Ghana, VAT was introduced in 1995 and withdrawn within three months and reintroduced in 1998, and the purpose of introduction of VAT was to deepen efficiency of the tax system as well as boosting the aggregate tax revenue share (Andoh et al., 2018).

In 2018 the South African government expected a revenue shortfall of R48.2 billion which was lower than the R50.8 billion projected in 2017 Medium Term Budget Policy Statement ('MTBPS'); however, this was higher than the 2016/2017 revenue gap of R30.7 billion (National Treasury, 2018:37). This situation was critical and call for a decision to make to come up with policy measures that could increase revenue by R36 billion in $2018 / 2019$ as the debt to GDP ratio was standing at $53.3 \%$, an indication in this regard, could result in more drastic spending cuts and risk high tax increases in the future (National Treasury, 2018:37). Emanating from the situation, the 2018/2019 tax proposals, suggested a $1 \%$ increase in VAT, which resulted in VAT rate moving from $14 \%$ to $15 \%$. In these proposals, it was also decided not to adjust the top four income tax brackets and below inflation adjustment on the bottom brackets. Emanating from the proposal, in dealing with the expected R36 billion revenue shortfalls that needed to be raised, the most considerable contribution came from VAT in an amount of R22.9 billion, resulting from the $1 \%$ increase and the remainder of R13.1 billion came from other taxes. It can, therefore, be argued that VAT, has been used as a rescuer to the fiscal objectives because these increases will help meet the new spending commitments and also prevent any further erosion of the public finances. In 2003, Lesotho established Lesotho Revenue Authority and introduced VAT that replaced the General Sales Tax. In Lesotho VAT, is the main driver of tax revenue and it is more elastic than Pay as You Earn. A study by Koatsa and Nchaka (2017) on the study of revenue productivity of the tax systems, found that there is a potential for VAT, to raise more revenue for the government. It can, therefore, be argued that the buoyancy of VAT will assist the government in getting the revenue necessary to meet its fiscal obligations.

In Uganda, VAT was introduced in 1996 to replace sales tax, the reason for the introduction of VAT, was because of its higher revenue potential as compared to the sales tax (Ayoki, Obwona \& Ogwapus, 2005). Ayoki et al. indicated that the largest share of tax revenue in Uganda originated from VAT, and the second that follows VAT in terms of revenue contribution was is import duties. It can, therefore, be inferred that even in this instance, VAT contributed the largest share of the revenue. In this study, it was also indicated that countries like Kenya, Lesotho, Mauritius, Namibia and South Africa, despite their low rates, they have large ratios of tax revenue when compared to their GDPs. According to Cnossen (2015), several countries in Africa increase their tax revenue to fund their fiscal obligations like human and economic development. In order to meet these fiscal obligations, VAT is the main used instrument because it is less detrimental to the growth as contrasted to income taxes. The fundamental view is that VAT return proceeds from the notion; VAT is expected to raise revenue efficiency and predictability (Cnossen, 2015).

In order to improve the domestic resource mobilisation, VAT is a potential candidate that is used by developing countries (Godin, Houssa \& Megersa, 2017). Godin et al., concludes that the performance of VAT over the years has improved and closed the resource gap by implementing reform and that has improved the efficiency of the VAT system. VAT revenue in South Africa has increased from R70 billion to R238 billion in the years 2003 to 2013 (IMF, 2015). VAT as a consumption tax that becomes payable on acquisition of the good or service is regarded as being broad-based and present the best collection trends in the OECD countries and is therefore regarded as the most efficient tax system (Penda \& Tarh, 2018). VAT has the propensity to eliminate the cascading effect; however, it requires close monitoring as there are possibilities of reselling problems (Penda \& Tarh, 2018).

\section{WHETHER OR NOT THE VAT IMPROVE THE COUNTRIES FISCUS OBLIGATIONS?}

Countries experience budget shortfall from time to time, and they are always looking for fiscal remedies to resolve the situations VAT, becomes the best option. In March 2017 SARS experienced a R30 billion shortfall, which was attributed to economic pressures and not incompetence of SARS officials. The magnificence of VAT is that it is self-enforcing and it is a buoyant tax despite, the possibilities of fraudulent activities in the system. A VAT is a destination based tax that uses credit method. VAT is in many countries where it has been adopted as the second most important source of revenue after personal tax. VAT is a tax that is regarded as being efficient because it has built-in capabilities that always for a minimal level of distortion. 
In many jurisdictions as a measure to increase efficiency and some small vendors are excluded. In order to promote the principle of equity and fairness, VAT is non-regressive, and its progressiveness is mild because it also makes provision for zero ratings. On the element of transparency and certainty, VAT can be regarded as transparent both in theory and practice, and it also provides a high degree of certainty when it comes to the level of flexibility and buoyancy; it can be regarded as being a buoyant tax. According to Andoh, Osoro and Luvanda (2018), VAT is the recommended choice that can boost tax revenue in the developing countries this is despite the contrary, new impact of VAT in Ghana. The evidence from Ghana on the implementation of VAT has proven differently that VAT, did not contribute as expected and therefore cannot be said to have brought any significant improvement on the aggregate tax. It was therefore concluded that the level of concentration that is usually given to VAT, should be reduced, and focus is on an appropriate balance of tax mix rather than focusing on one (Andoh et al., 2018). The situation in Ghana was however an exception rather than the norm, as the performance in other countries have been different. In the assessment of the performance of taxes, it was revealed that contrary to the other taxes, Value Added Tax has increased (DFID, 2013:9). VAT is regarded as an instrument of choice that developing countries should use if they are contemplating replacement concerning the sales tax. It was concluded that in the research by AERC (1998), that VAT provides for more significant revenue, tax neutrality, economic efficiency and it also provides at time for the vertical equity albeit to a limited extent. It was also indicated that VAT, has earned itself a reputation as "money machine" due to how it can generate a considerable amount of revenue quickly and in a comparatively painless fashion.

\section{CONCLUSION}

It is evident from the above discussion that compliance times in tax remain necessary under any tax system; however, the reduction of compliance costs will have a stimulus effect on the economy of a country. Emanating from the discussion of principles of taxation as outlined above, they may be interpreted in according to the broader principles in the area of social justice that demand that taxation be not only been equitable in the sense of impartiality but, it should be an element of fairness. It is also evident that consideration should be given to the ability to pay, who benefits and the cost of service theories as they are also designed in such a way that reduces economic inequalities and has the ability to redistribute wealth. It can, therefore, be concluded that the power of taxation proceeds upon the theory that the existence of government is a necessity that it cannot continue without means to pay its expenses; and that for these means it has a right to compel all its citizens and property within its limits to contribute. The basis of taxation is found in the reciprocal duties of protection and support between the state and its inhabitants in return for the contribution, the taxpayer received benefits and protection from the government, and this is the so-called benefit received. It can be further concluded that there is an improvement in the economic conditions of the country where there is VAT. It also becomes evident in this article that the intensification of the processes of audit increases the levels of efficiency in the tax system and enables the country to have the resources to meet its fiscal obligations.

\section{REFERENCES}

Aasness, J., Benedictow, A and Hussein, M.F. 2002. Distributional Efficiency of Direct and Indirect Taxes. Rapport 69. Economic Research Programme on Taxation. Statistisk Sentralbyra.

AERC.1998. Tax Reform and Revenue Productivity in Ghana. Africa in Economic Research Consortium. The Regal Press Kenya Ltd. Nairobi. Kenya.

Andoh, F.K., Osoro, N.E and Luvanda, E. 2018. Is Value Added Tax a Moneymaking Machine for Developing Countries Economies? Evidence from Ghana. African Journal of Economic Review. Volume.VI. Issue II. 1 -26

Aspromourgos, T. 2001. What is Classical Economics? History of Economics Review. Cambridge Journal of Economics. 159168.

Ayoki, M., Obwona, M and Ogwapus, M. 2005. Tax Reform and Domestic Revenue Mobilisation in Uganda. Institute of Policy Research and Analysis. Economic Policy Research Centre. Ministry of Finance, Planning and Economic Development. Uganda.

Batt, H.W. 2012.Tax Regimes that do not invite corruption. International Journal of Transdisciplinary Research. 6 (1):65 82.

Bird, R.M. and Zolt, E.M. 2003. Introduction to Tax Policy Design and Development. Practical Issues of Tax Policy in Developing Countries, World Bank. April 28 - May 1, 2003.

Chigbu, E.E., Eze, A.L and Ebimobowei, A. 2012. An Empirical Study on the Causality between Economic Growth and Taxation in Nigeria. Current Research Journal of Economic Theory. Maxwell Scientific Organisation. 4(1):29-38.

Cnossen, s. 2015. Mobilizing VAT Revenues in African Countries. International Tax and Public Finance. University of Pretoria. https://doi.org/10.1007/s10797-015-9348-1

Croome, B and Olivier, L. 2010. Tax Administration. Juta \& Co. First Floor, Sunclare Building, Claremont.

Dalton, H., 1992. Principles of Public Finance. Routledge Library Edition.2 Park Square, Milton Park Abington, Oxon OX14 4RN.

De Long, J.B. 1982. The Classical Economists Perceive the Industrial Revolution. Harvard College.

DFID. 2013. Taxation and Developing Countries - Training Notes. Economic and Private Sector Professional Evidence and 
Applied Knowledge services. Structured Professional Development.

Ebimobowei, A and Ebiringa, O.T. 2012. Petroleum Profit Tax and Economic Growth in Nigeria. International Journal of Management Sciences and Business Research.

Fjeldstad, O. and Moore, M. 2009. Revenue Authorities and Public Authority in Sub-Saharan Africa. Chr Michelsen Institute Bergen. Norway. https://doi.org/10.1017/S0022278X08003637

Gemmell, N., Morrissey, O and Pinar, A. 2010. Taxation, Fiscal Illusion and The Demand for Government Expenditure in the United Kingdom: A Time Series Analysis. Discussion Paper. School of Economics. Nederlandse Organisatie voor Wetenschapelijk Ondersoek.

Go, D.S., Kearney, M., Robinson, S and Thierfelder, K. 2004. An Analysis of South Africa's Value Added Tax. https://doi.org/10.1596/1813-9450-3671

Godin, M., Houssa, R and Megersa, K. 2017. The Performance of VAT in DGD-Partner Countries: Centre of Research in Economics of Development. University of Namur.

Huxham, K. \& Haupt, P. 2018. Notes on South African Income Tax 2010. $31^{\text {st }}$ Edition. Roggebaai: Hedron Tax Consulting and Publishing.

IMF.2015. Technical Assistance Report - Revenue Administration GAP analysis program- The Value Added Tax Gap. IMF Country Report No.15/180. International Monetary Fund. Publication Services. Washington D.C.

Koatsa, N.J and Nchake, M.A. 2017. Revenue Productivity of the Tax System in Lesotho. Department of Economics. National University of Lesotho.

Lynham, S.A. 2002. The General Method of Theory-Building Research in applied disciplines. Advances in Developing Human Resources. SAGE publications. https://doi.org/10.1177/15222302004003002

Martinez-Vazguez, J. 2001. The Impact of Budgets on the Poor: Tax and Benefits Incidence. Georgia State University.

Mylek, J. 2008. Literacy - Fundamental to Economic Development. The Open Polytechnic of New Zealand.

National Treasury. 2018. 2018 Budget Review. Pretoria. South Africa.

Penda, A.S and Tarh, BGM. 2018. The Buoyancy of the Value Added Tax on Economic Development: Its Drifts and Challenges. International Journal of Advanced Research. Vol.7. Issue 2. 80-106. https://doi.org/10.21474/IJAR01/8465

Pfister, M. 2009. Taxation for Investment and Development: An Overview of Policy Challenges in Africa. Ministerial Meeting and Expert Roundtable. NEPAD - OECD. African Investment Initiative.

Rai, P.K. 2004. The Challenges of Tax Collection in Developing Economies (with Special Reference to India). LLM Theses and Essays. University of Georgia.

Slemrod, J. 2007. Cheating Ourselves: The Economics of Tax Evasion. Journal of Economic Perspectives. Winter. 21(1):25-48. https://doi.org/10.1257/jep.21.1.25

Smith, A. 2005. An enquiry into the nature and causes of the wealth of nations. Electronic classics series publications. Pennsylvania State University.

Smith, L. 2003. The Power of Politics: The performance of South African Revenue Service and some of its implications, Policy /issues and actors. 16 (2). 1- 17.

Waris, A. 2007. Taxation without principles: historical analyses of the Kenyan Taxation System. Kenyan Law Review. 1:272.

Weber, K. 2012. Critical comparison of European Documentary Evidences in the context of Intra- Commonly supplies. Department of Management and International Business. Aalto University School of Business.

Welman, J.C., \& Kruger, S.J. 1999.Research Methodology for business Administrative Sciences. Oxford University Press. Great Clarendon Street, Oxford ox2 6DP.

Welp, M., de la Vega-Leinert, A.C., Stoll-Kleemann, S \& Furstenau, C. 2006. Science-based stakeholder dialogues in climate change research. Berlin. Heildelberg: Springer - Verlag. https://doi.org/10.1007/978-3-540-36917-2 8

Williams, R.C. 2001. Income Tax and Capital Gains Tax in South Africa: Law and Practice. Third Edition. Butterworths Tax Publishing. Durban.

World Bank. 2007. Worldwide Governance Indicators 1996-2007. Accessed May 2019 from http://www.worldbank.org/wbi/ governance.

Young, H.P. 1986. Progressive taxation and equal sacrifice principle. Journal of Public Economics. North Holland. 32 (1987):203214.

https://doi.org/10.1016/0047-2727(87)90012-0

Zhou, G., and Madhikani, A. 2013. Systems, Processes and Challenges of Public Revenue Collection in Zimbabwe. American International Journal of Contemporary Research. 3(2).

Zott, C., Amit, R and Massa, L. 2010.The Business Model: Theoretical Roots, Recent Development, and Future Research. Working Paper. WP - 862. IESE Business School, University of Navarra. https://doi.org/10.2139/ssrn.1674384

\section{DOI: https://doi.org/10.6000/1929-7092.2019.08.120}

(C) 2019 Chauke and Sebola; Licensee Lifescience Global.

This is an open access article licensed under the terms of the Creative Commons Attribution Non-Commercial License (http://creativecommons.org/licenses/by-nc/3.0/) which permits unrestricted, non-commercial use, distribution and reproduction in any medium, provided the work is properly cited. 